\title{
Short Communication: Using wildlife for local livelihood - Experiences from the Bird's Head Peninsula, West Papua, Indonesia
}

\author{
FREDDY PATTISELANNO ${ }^{1,2, \boldsymbol{v}}$, JOHN R. M. APITULEY ${ }^{3}$, AGUSTINA Y. S. AROBAYA ${ }^{4}$, JOHAN F. KOIBUR ${ }^{1,2}$ \\ ${ }^{1}$ Faculty of Animal Science, Universitas Papua. Jl. Gunung Salju Amban, Manokwari 98314, West Papua, Indonesia. Tel./fax.: +62-986-211455, \\ "email: f.pattiselanno@unipa.ac.id, pattiselannofreddy@yahoo.com \\ ${ }^{2}$ Biodiversity Research Center, Universitas Papua. Jl. Gunung Salju Amban, Manokwari 98314, West Papua, Indonesia \\ ${ }^{3}$ Faculty of Economics, Universitas Negeri Manado. Jl. Kampus UNIMA, Tonsaru, Tondano 95618, North Sulawesi, Indonesia \\ ${ }^{4}$ Faculty of Forestry, Universitas Papua. Jl. Gunung Salju Amban, Manokwari 98314, West Papua, Indonesia
}

Manuscript received: 12 February 2019. Revision accepted: 13 June 2019.

\begin{abstract}
Pattiselanno F, Apituley JRM, Arobaya AYS, Koibur JF. 2019. Short Communication: Using wildlife for local livelihoodExperiences from the Bird's Head Peninsula, West Papua, Indonesia. Biodiversitas 20: 1839-1845. Wildlife products are valuable commodities, and wild meat is considered as premium value because it has a high value per unit weight compared with other forest products Wildlife products are commonly used for consumption purpose, generating household income and cultural reasons. Because cultural values differ among ethnic groups, it is important to understand how wildlife contributes to local livelihoods in different areas of the Bird's Head Peninsula. Data was obtained opportunistically during fieldwork to different parts of West Papua Province from 2010 to 2018. Study sites were not intentionally selected, but they were considered during the involvement of authors in research and survey across the Bird's Head Peninsula of West Papua Province Data was collected through indirect observation and semi-structural interviews. A literature review was also completed to supplement the primary data collected from the fieldwork. The results indicated many people rely on wild meat as an alternative source of food for the household. Wildlife also offered forms of income generation such as sale of bushmeat products. Acquisition of animal parts as cultural artifacts, for personal adornment or for trophies was still a widespread practice throughout the areas. Religious and cultural aspects also contributed significantly to the use of wild meat for traditional or spiritual aspects as well. Finally, some reasons have been identified that derive peoples' attitudes in using wildlife across the Bird's Head Peninsula, and they are for consumption, sale and the relationship between wild animal species and cultural values.
\end{abstract}

Keywords: Cultural, food, income, local livelihood, Papua, wildlife

\section{INTRODUCTION}

Using wildlife is closely linked to many cultures throughout the world's tropical forests. Using wildlife in tropical forests is generally done to obtain food, generate income or for cultural reasons (Robinson and Bennett 2000). While domesticated livestock is the vast bulk of the (terrestrial) meat eaten today by humans, in some contexts wild meat remains an important, and sometimes crucial, food source for millions of humans (Cooney 2013). Some in the scientific literature argues that in tropical forests wildlife is mostly used for subsistence purposes ( $\mathrm{Fa}$ and Brown 2009; Milner-Gulland et al. 2003; Robinson and Bennett 2000).

Fact shows that wild meat contributes significantly to rural communities in Asia, Africa, and Latin America because it is more easily accessible than cultivated meat, and is often the most available dietary protein (Rao and McGowan 2002). In tropical areas worldwide, wild meat has long been part of the staple diet of forest-dwelling peoples (Fa and Yuste 2001), and is a major source of protein for many people living in or close to tropical forests today (Bennett et al. 2000). Using wildlife for food also varies between communities. Some people consume it because it is affordable, familiar, and (depending on cultural background) it can be considered a meal for the elite class. Others value wild meat for its taste and the fact that it offers variety for the household diet (Wilkie et al. 2005).

The preferences for different wildlife species are usually influenced by economic activity, access to domestic meat, ethnic origin, geographical isolation, local wildlife availability and the biological attributes of species that are hunted (Naranjo et al. 2004). In addition, other factors have influenced prey preference, such as the social, cultural and political characteristics of the ethnic groups that hunt (Fa et al. 2002a).

Little appears in the scientific literature about the importance of wildlife in West Papua. Research on using wildlife and its contribution to local livelihood, including different cultural approaches in using wildlife and threats to wildlife populations, therefore, is important to fill this gap in knowledge particularly at different areas on the Bird's Head Peninsula of West Papua, Indonesia. 


\section{MATERIALS AND METHODS}

\section{Study area}

Data were obtained during opportunistic visits on eight sites, i.e. Abun (Tambraw), Amberbaken (Manokwari), Kebar (Manokwari), Arfak (Pegunungan Arfak), Maybrat (Maybrat), Sebyar (Teluk Bintuni), Tembuni (Teluk Bintuni), and Bomberai (Fakfak), from 2010 to 2018 . Study sites were not intentionally selected, but they were considered during the involvement of authors in research and survey across the Bird's Head Peninsula of West Papua Province, Indonesia (Figure 1).

Abun and Amberbaken, located on the coastline and adjacent to rocky hill areas, consisted of more hilly areas and mountainous parts. The areas were mostly covered by primary forest and secondary forest. Ipomoea pescaprae and Scaevola serillae were mostly dominated vegetation across the coastal forest the seaward. In the landward Barringtonia asiatica, Terminalia catappa, and Pandanus were the dominant vegetations. The major livelihood in this area is farming, while hunting plays important role for supporting animal protein consumption. World Wildlife Fund (WWF), had a long term program within the areas, in collaboration with local university and NGOs because of the importance of nesting beaches for the leatherback Olive Ridley, Greens, and Hawksbill turtles.

The area we surveyed at Arfak Mountain was at about $2000 \mathrm{~m}$ altitude, in an area of low very open scrub, with only a few stunted Baeckea (Myrtaceae) bushes. Several Rhododendron species were present and other Ericaceae, such as Vaccinium, as is normal in these Baeckea scrub areas. We also observed some species from family
Myrtaceae, Podocarpaceae, and Rutaceae around the study sites. People were most involved in shifting cultivation supported by subsistence hunting for household consumption. They also made money by selling leek (Allium porrum), main agricultural products to the market in Manokwari. Biodiversity conservation program at Arfak Mountain was carried out by Paradiseae (local NGO) with local government. Currently, WWF is working to identify high conservation value within the corridor that connected Arfak, Tambrauw and South Manokwari regencies to support biodiversity conservation in the areas.

Upland Kebar (Kebar Valley) located along east trending Pleistocene/Holocene intermontane basin, which is enclosed by fault-bounded mountains up to $2000 \mathrm{~m}$ high, and $2,703 \mathrm{~km}^{2}$ wide. Across the primary forest, we found large trees such as Intsia bijuga, covered by epiphyte canopy. Forest grounds were mostly covered by shrubs, ferns, and mosses. In secondary forest small diameter trees like matoa (Pometia pinnata), binuang (Octomeles sumatrana), damar (Araucaria, sp.) were mostly found. In some spots, other tree species were found such as: kayu merah (Homalium foetidum), pulai (Alstonia spp.), sukun (Artocarpus communis), rattan (Calamus spp and Korthalsia sp.), and pandan (Pandanus sp.). Household income in this area is generally agriculture based with major product is peanut. Subsistence agriculture was dominant in Kebar, while hunting was usually conducted to support local livelihood. Several local NGOs worked together here supporting the community development program with special aim to reduce people reliance on biodiversity resources.

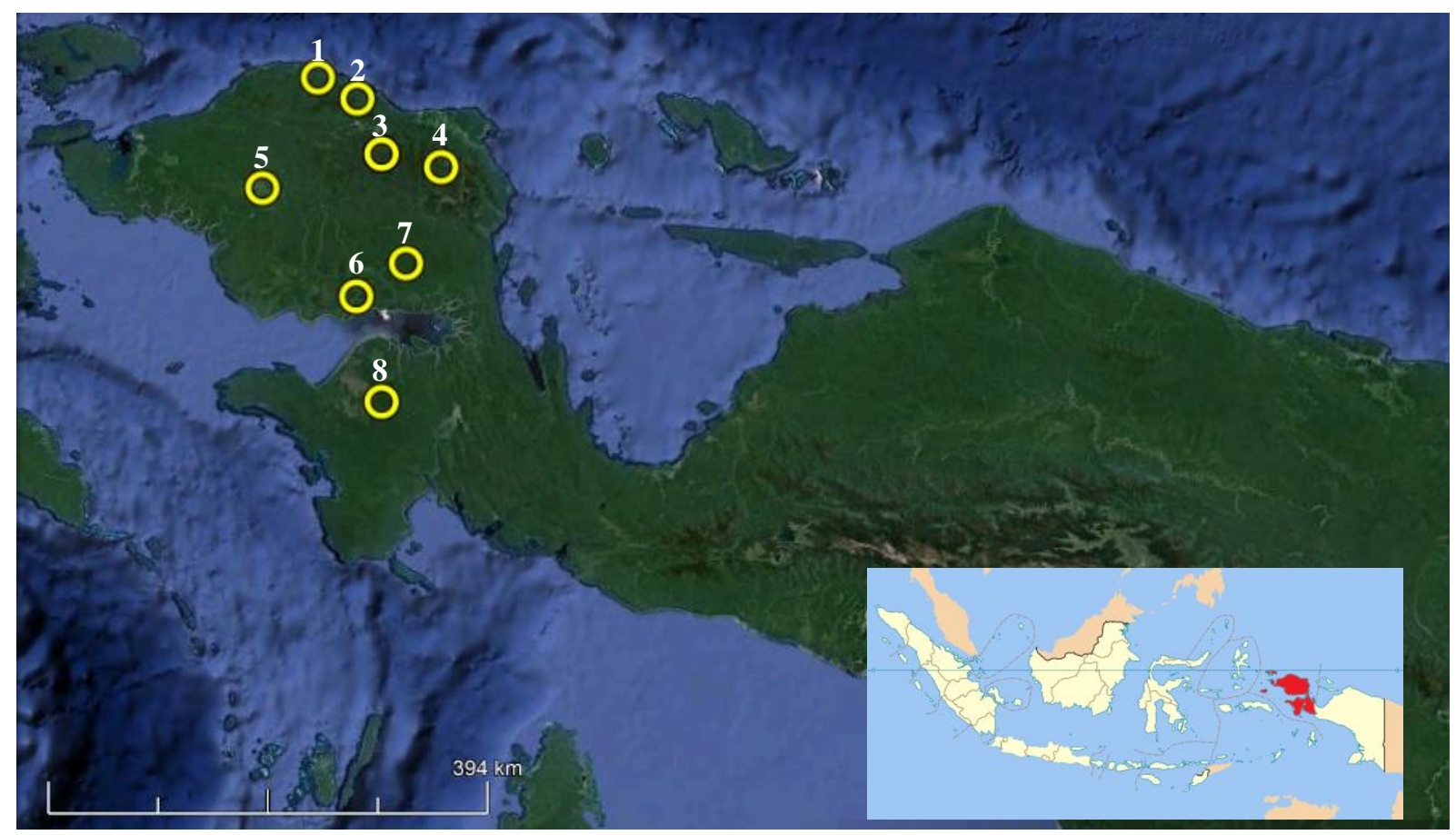

Figure 1. Distribution of study areas across The Bird's Head Peninsula of West Papua Province, Indonesia. Large dots represent sites in this study: 1. Abun (Tambraw), 2. Amberbaken (Manokwari), 3. Kebar (Manokwari), 4. Arfak (Pegunungan Arfak), 5. Maybrat (Maybrat), 6. Sebyar (Teluk Bintuni), 7. Tembuni (Teluk Bintuni), and 8. Bomberai (Fakfak), 
Table 1. List of questions asked in interview and questionnaire

1. Why do you hunt?

2. What animals are hunted, and what for?

3. What animals are not allowed to hunt? Why?

4. Who buys your catch?

5. Are animals less or more difficult to catch in the last five years? Why?

6 . Any customary rules are applied in using wildlife species within the community?

Notes: Question No 1-4 were asked to key respondents $(\mathrm{N}=80)$; Question No 1-6 were randomly distributed to respondents excluding key respondents $(\mathrm{N}=160)$

The topography of Maybrat is quite varied from highlands with mountainous and slopes areas $\pm 65 \%$ to lowlands (wetland and coastal) approximately $35 \%$. Stands found in these sites dominated by Araucariaceae family such as Agathis and Araucaria growing mainly in lowland and some moderate altitudes to mountainous and highland forests. People are relied on shifting cultivation with hunting to supply the need for animal protein.

Mangrove (Avicennia alba, Sonneratia alba, and Rhizophora apiculate) were dominant species found along the out layer belt of Sebyar River. Bruguiera spp. and Metroxylon sago were mostly dominated the inside part of the belt. Forest areas were far from the water body, and grown by Papuan nutmeg (Myristica argentea), Meranti (Shorea sp.), Ketapang (Terminalia catappa) and Jambu Hutan (Eugenia sp). Close to the water body, flat areas were utilized as the settlement. Local livelihood was more derived from subsistence agriculture and fishing. Some villages that have direct impact form the LNG Tangguh Industry was regularly involved in the DAV program, and obtain specific program on community development. More deeply into the forest areas in Tembuni, large trees such as Meranti (Shorea sp.), Intsia bijuga and binuang (Octomeles sumatrana) are mostly found. Moreover, streams and river banks mostly found at the low landscape, utilized by communities to collect shrimp and fish for local consumption

In Bomberai, the premier forest was dominated by Intsia bijuga, Pometia pinnata, and Dracontomelon dao, while the rest of the areas are savanna that found homogenous and easy to fire during the dry seasons. These specific habitats were more suitable for deer (Cervus timorensis) and wild pig as hunting target surrounding the areas. Mangrove forests are also found in this site and considered as fishing ground to local communities. Source of livelihood is agriculture and hunting is performed during working at the farmland.

\section{Procedures}

Data was collected through 2 survey instruments. (i) To gain information on wildlife used by local communities we approached the village chairman or secretary help identify 10 active hunters-those interviewed as key respondents ( $\mathrm{N}$ $=80$ ) in each site (Kaltenborn et al. 2005). (ii) To get overall picture on using wildlife, we also randomly distributed 20 questionnaires in each site, excluding 10 active hunters (Pattiselanno and Lubis 2014). Our target was people from different backgrounds across the whole community in the sampled villages. A total of 160 questionnaires were returned for analysis. Question asked for both interview and questionnaire were in Table 1. A literature review was also completed to supplement the primary data collected from the fieldwork.

\section{Data analysis}

All the observation results obtained in this study were analyzed using descriptive statistics. The data obtained were analyzed and displayed in graphs, figures, and tables. Contextual approach was used to explain the situation in the field in order to complete description of the study sites.

\section{RESULTS AND DISCUSSION}

A wide range of animals is used by different ethnic groups. There are introduced species such as deer and wild pig as well as native species, for example, cassowaries and parrots (birds), cuscuses, wallabies, tree kangaroos and bandicoots (mammals) in terrestrial ecosystems. Herpetofauna species (crocodiles and turtles), are used along with the coastal and swampy sites for various purposes. According to Robinson and Bennett (2000), wildlife in tropical forests is mostly used to obtain food, generate income or for cultural reasons. Using wildlife in tropical forests is mostly for the purpose of subsistence ( $\mathrm{Fa}$ and Brown 2009; Milner-Gulland et al. 2003; Robinson and Bennett 2000). Animal-based foods supply many important micronutrients in much higher amounts or with higher bioavailability than most plant-based foods (Siekmann et al. 2003). The decision to consume or sale wildlife products depends not only on the hunter's nutritional and economic status, but also on the other opportunities available for food and income generation (Milner-Gulland et al. 2003).

\section{Wildlife for food}

Available food source from wildlife and limited access to livestock products as the animal protein food sources were the major reason to acquire wild animals for consumption. People kept livestock such as chickens, goats and pigs in small number. The motivation for keeping livestock was mainly associated with the need for income and savings against future needs. For example, people 
commonly cited the need for cash to pay education costs. In addition, the livestock may be consumed on special occasions such as festivals, but are not for daily consumption. In all study sites, wildlife for food was obtained through hunting. Providing the household with complete meals including meat was important to our respondents and we found that wildlife meat contributed to household consumption. Most of the respondents involved in agriculture, and crop-lands allow the production of carbohydrates from tuber crops and bananas. However, croplands do not provide animal protein to the households and, thus meat from the wild is important to supply the requirement for animal protein for these people. During the study, we recognized meat from different wildlife was served for consumption purpose (Table 2). Detailed interview with those who prepared food indicated that deer and wild pig meat were most commonly prepared for feast.

\section{Wildlife support income generation}

Despite the main purpose of using wildlife being to provide food for household consumption, in this study, trading is also important. Ninety-two point five percent of interviewees $(\mathrm{N}=160)$ declared that using wildlife for earning extra income was also important (Figure 2).

Although there is no formal market for wildlife products, the sale of wild meat to traders provides cash to the hunters. In this study, meat from deer and wild pig were the most sale products in all sites. The involvement of key respondents in meat trading is presented in Table 3. Species used in trading is dominated by deer and wild pig as they provided the largest amount of meat to supply wild meat to the consumers in surrounding villages and town.

\section{Wildlife and culture}

Some reasons that derive peoples' preferences are the presence and the abundance of prey species, difficulties in hunting the animals and the relationship between species and cultural values (Figure 3).

Cultural reasons have been highly considered in using wildlife. The interaction between wildlife and culture is clearly shown by the use of animal parts for cultural artifacts and traditional costumes such as plumes of particular bird's species, feathers, skins and teeth of mammal species in almost all areas of West Papua province. For certain reasons, pigeon and birds of paradise are serving as religious symbol or their ancestor originated. People acquire them as symbol, emblem or totem to their tribe, so those birds are conserved indirectly.

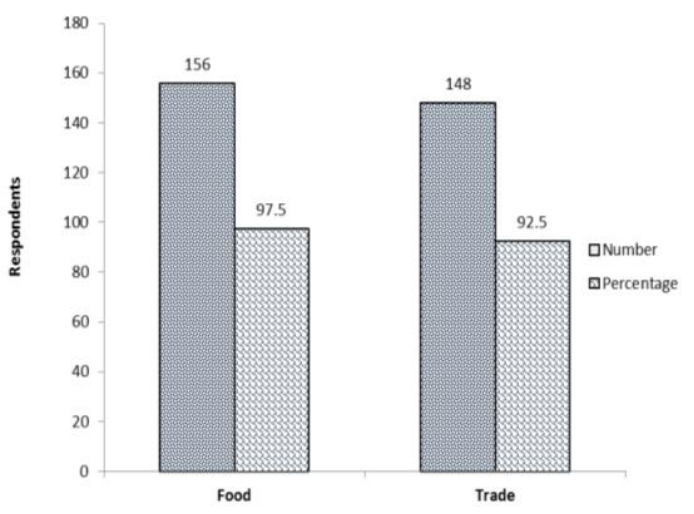

Figure 2. The purpose of using wildlife within the study sites obtained from questionnaires distribution $(\mathrm{N}=160)$

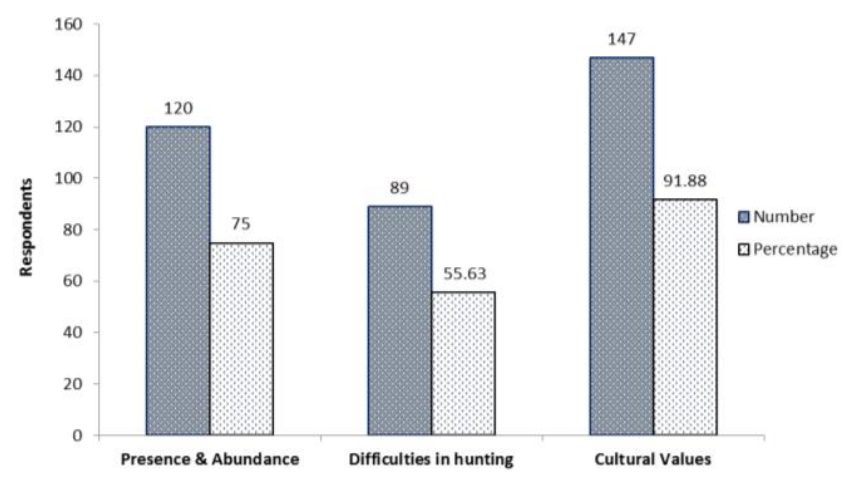

Figure 3. The reasons for using wildlife-data from questionnaires distribution $(\mathrm{N}=160)$

Table 3. Percentage of key respondents $(N=80)$ involved in deer and wild pig meat sale

\begin{tabular}{lcc}
\hline Study sites & Deer $(\boldsymbol{\%})$ & Wild pig $(\boldsymbol{\%})$ \\
\hline Abun & 100 & 80 \\
Amberbaken & 100 & 90 \\
Arfak & 0 & 40 \\
Bomberai & 100 & 50 \\
Kebar & 90 & 60 \\
Maybrat & 70 & 90 \\
Sebyar & 60 & 30 \\
Tembuni & 100 & 80 \\
\hline
\end{tabular}

Table 2. Species hunted for consumption purpose data obtained from key respondents $(\mathrm{N}=80)$ across the study sites at the Bird's Head Peninsula

\begin{tabular}{lll}
\hline Species & $\%$ & Study sites \\
\hline Deer (Cervus timorensis) & 95.00 & Abun, Amberbaken, Arfak, Bomberai, Kebar, Maybrat, Sebyar, Tembuni \\
Wild pig (Sus scrofa) & 87.50 & Abun, Amberbaken, Arfak, Bomberai, Kebar, Maybrat, Sebyar, Tembuni \\
Cuscus (Phalangeridae) & 45.00 & Abun, Amberbaken, Arfak, Maybrat \\
Bandicoot (Peroryctidae) & 71.25 & Abun, Amberbaken, Arfak, Kebar, Maybrat \\
Cassowary (Cassuaridae) & 62.50 & Abun, Kebar, Maybrat, Sebyar, Tembuni \\
Ducula pinon & 37.50 & Amberbaken, Bomberai, Maybrat, Sebyar \\
Dendrolagus inustus & 35.00 & Arfak, Maybrat, Tembuni \\
\hline
\end{tabular}




\section{Discussion}

The extreme connections between humans and animals have existed throughout history (Alves 2012a). The importance of faunal derived products have been acknowledged and used in many ways, especially as food, but also as clothing and tools, and for medicinal and magicreligious purposes (Alvard et al. 1997; Alves et al. 2009; Alves and Pereira Filho 2007; Inskip and Zimmermann 2009; Prins et al. 2000). This study found that, using wildlife for food varies between communities. Some people consume it because it is affordable, familiar, and (depending on cultural background) it is acknowledged as a high-quality meal. Limited access to livestock products and the abundance of wildlife across the study sites were the reasons for using wild meat for food.

In this study, deer and wild pig the most hunted species. Regarding cultural attitudes towards animal species consumed by the Muslim fellows, pork is not allowed to consume. In this case, venison that has no religious restrictions was transported to the nearest district where the meat was sold to ethnic non-Papuans, mostly Muslim at the transmigrant settlements. Wild meat was valued for its taste and the fact that it offers variety in the household diet (Wilkie et al. 2005). The need for wild meat consumption as an animal protein source in the study sites is very important. In the Congo Basin, for example, families in rural areas consume ten times the amount of wild meat compared to those in urban sites (Wilkie and Carpenter 1999). Studies show that wild meat contributes significantly to rural communities in Asia, Africa, and Latin America because it is more easily accessible than cultivated meat, and is often the most available dietary protein (Rao and McGowan 2002). Prescott-Allen and Prescott-Allen (1982) therefore, suggested that people in as many as 62 countries are primarily dependent on wild animal meat as a protein source.

Respondents in this study also acknowledged that livestock (beef and chicken) may be consumed on special occasions such as festivals, but are not for daily consumption. This also experienced by other tropical forest regions, where livestock such as beef and chicken may be eaten at special occasions like festivals or ceremonies but not for daily consumptions. The consumption of large amounts of meat/fish was considered a luxury even for the wealthiest households and limited to festivities, such as Christmas or the birth of a child. During such occasions, livestock would be slaughtered and large amounts of meat were consumed (Schulte-Herbrüggen et al. 2017). Some are mostly kept as "money in the bank" and sold during emergencies or times of hardship for cash (Bennett 2002; Milner-Gulland et al. 2003). For those without access to capital, land or livestock, the harvest of wildlife resources may offer the best return for effort in household livelihoods (Nasi et al. 2008).

A significant proportion of the wildlife biomass hunted by humans for food across the tropics, especially largebodied primates, ungulates and rodents (average weight greater than $1 \mathrm{~kg}$ ), is found in tropical rainforests, with ungulates and sometimes rodents dominating the biomass in more open habitats (Robinson and Bennett 2004).
Likewise, our findings showed that ungulates species (deer and wild pig) contributed significantly to both consumption and trade across the study sites.

Similar to our findings, Chaves et al. (2017) indicated that occupation was an important predictor of consumption, with farmers (the most common occupation in our study sites), consuming more wild meat than people with other occupations. Generally, urban consumers have access to a wide range of meat/fish types and the high price of bushmeat makes it an expensive commodity that is frequently consumed only by a wealthy minority (Fa et al. 2009; East et al. 2005; Wilkie et al. 2005). In contrast, bushmeat is relatively inexpensive in rural areas, often hunted by the consumers themselves, and alternatives are both less readily available and generally more expensive than bushmeat (Brashares et al. 2011; Elliott 2002).

Wildlife products are valuable commodities, and wild meat is considered as premium value because it has a high value per unit weight compared with other forest products (Williamson 2002). Despite the importance of wild meat for consumption, our data expresses that in all sites, wildlife trade is also essential for local livelihoods. Further information gathered during interviews indicated that the local price per kilogram being 25,000 Indonesian Rupiah (IDR) (equals to US\$ 1.89) for venison and 15,000 IDR (or US\$1.13) for pork. In this study, the harvest rates of particular species were also more likely to be influenced by market demand and consumer preference for particular wild meat. Wild meat was rarely sold to other villagers within a village, but passed into the city and sold at the local markets, and the price was increased two folds.

In contrast to studies from Africa (Davies 2002; Wilkie and Carpenter 1999), the bushmeat trade in this study was still a relatively small economic activity. According to Falconer (1992) and Ntiamoa-Baidu (1992), price can vary remarkably across bushmeat species because of their intrinsic value (i.e. taste) and independently on the weight of the sold meat. In cultural contexts, preferences for its taste has often been considered as the main reason for buying bushmeat, across the African countries (Schenk et al. 2006; Njiforti 1996; Wright and Priston 2010; Falconer 1992; Ntiamoa-Baidu 1992). Other studies also supported the previous statement (e.g., Fa et al. 2000; MacDonald et al. 2011; Van Vliet et al. 2011), suggesting that selective harvesting can indicate that hunters catch species according to the preference of the consumers (Wright and Priston 2010).

Across the humid tropics, millions of people rely on using wildlife for an alternative source of family revenue. Research has found that the majority of those involved in wildlife trading belongs to low economic status households. In this study, income of respondents was not collected, but an income median the respondents in Abun and Amberbaken ranged of between IDR 1,100,000 and IDR 1,300,000. Studies from different parts of the world revealed the significant contribution of wildlife as a source of cash for households living in extreme poverty (with daily per capita less than US\$1), particularly during lean agriculture seasons (Mendelson et al. 2003; Hilaluddin et al. 2005). These studies support research by Shively (1997) 
that local Pala'wan households of the Philippines, with an average annual income of less than USD 400 per household, also hunted meat for food and extra income.

Integration of wildlife utilization to the market increases harvest rates (Robinson and Bennett 2004). Commercialisation of wild meat in the Ituri forest, for instance, increased net harvest intensity of duiker (Hart 2000). Access to the market not only increases the used of frequently hunted target species such as tapir, but also threatens other species including collared peccary $(T$. tajacu) and agouti (Dasyprocta spp.) (Bodmer and Puertas 2000). Consequently, the extension of the wild meat market outside the area also increases wild meat consumption (Bennett et al. 2000). Similar to other parts in Papua, although the hunting target varies from one site to another, wild pig and deer are the most commonly hunted species in all study sites, because they are widely distributed (Pattiselanno 2006; Pattiselanno and Arobaya 2009), and they provide a large amount of meat for both subsistence and sale purposes (Pattiselanno and Lubis 2014; Pattiselanno and Koibur 2018).

Wildlife uses is closely linked to many cultures throughout the world's tropical forests. Apart from uses as a food source, acquisition of animal parts as cultural artefacts, for personal adornment or for hunting trophies (most often skins, teeth, antlers and horns) is still a widespread practice throughout tropical forest regions and the rest of the world (Bennett et al. 2000; Fa and Brown 2009). In this study, Pigeon and Birds of paradise are not allowed to hunt, because people believe, they are religious symbols, so those birds are conserved. All human cultures have mythologies, and all of them show close integration and connections with animals, and totemic, ancestral or mythological (imaginary) animals or animal gods have been present throughout human history (Allaby 2010; Alves et al. 2012a).

The influence of culture plays a significant role in animal trophies obtained for cultural artifacts or for personal adornment in Papua New Guinea (Kwapena 1984). Fa and Brown (2009) assert that the use of wild animals can also be associated with obtaining medicine for human therapies and other traditional uses (note: most hard and soft body parts are used in some way). Trophies hunting are most commonly found across the sites. Throughout the Asian region, the use of indigenous wildlife is mostly conducted to supply the needs of traditional medicine (Corlett 2007). For that reason, the preferred prey of hunters in northern Myanmar are tigers, bears and pangolins (Rao et al. 2005) rather than food species like deer, pigs, primates, and porcupines found in the same area. Although in this study we did not find any application of wildlife for medication, Pattiselanno et al. (2015) indicated, culturally, using wildlife in Papua has a strong correlation with nature.

Our study did not find any information on the use of wildlife for therapeutic purpose. Further study is required to explore more information on medicinal animals. A study of Alves et al. (2012b) for example, found a total of 25 medicinal animals were cited by the interviewees in northeastern Brazil, included five taxonomic groups: mammals ( 8 species), insects ( 7 species), birds (4 species), reptiles (5 species), and amphibians (1 species) belonging to 19 families.

To summarize, some reasons have been identified derive peoples' attitudes in using wildlife across the Bird's Head Peninsula, and they are for consumption, sale and the relationship between wild animal species and cultural values. The preferences for different wildlife species are usually influenced by economic activity, access to domestic meat, ethnic origin, geographical isolation, local wildlife availability and the biological attributes of species that are hunted (Naranjo et al. 2004). In addition, other factors have influenced wildlife preference, such as the social, cultural and political characteristics of the ethnic groups (Fa et al. 2002b).

\section{REFERENCES}

Allaby M. 2010. Animals: from mythology to zoology. Facts on File Inc., New York.

Alvard MS, Robinson JG, Redford KH, Kaplan H. 1997. The sustainability of Subsistence Hunting in the Neotropics. Conserv Biol 11:977-982.

Alves RRN, Rosa IL, Léo Neto NA, Voeks R. 2012a. Animals for the Gods: Magical and Religious Faunal Use and Trade in Brazil. Hum Ecol 40:751-780.

Alves RRN, de Sousa Neta RO, de Brito Melo Trovão DM, de Lucena Barbosa JE , Barros AT, Dias TLP. 2012b. Traditional uses of medicinal animals in the semi-arid region of northeastern Brazil. $\mathrm{J}$ Ethnobiol Ethnomed 8(1): 41.

Alves RRN, Mendonça LET, Confessor MVA, Vieira WLS, Lopez LCS. 2009. Hunting strategies used in the semi-arid region of northeastern Brazil. J Ethnobiol Ethnomed 5: 1-50.

Alves RRN, Pereira Filho GA. 2007. Commercialization and use of snakes in North and Northeastern Brazil: implications for conservation and management. Biodivers Conserv 16: 969-985.

Bennett EL. 2002. Is there a link between wild meat and food security? Conserv Biol 16(3): 590-592.

Bennett EL, Nyaoi AJ, Sompud J. 2000. Saving Borneo's bacon: the sustainability of hunting in Sarawak and Sabah. In: Robinson JG, Bennett EL (eds) Hunting for Sustainability in Tropical Forests. (pp. 305-324) Columbia University Press, New York.

Brashares JS, Golden CD, Weinbaum KZ, Barrett CB, Okello GV. 2011. Economic and geographic drivers of wildlife consumption in rural Africa. Proc Natl Acad Sci 108: 13931-13936. https://doi.org/10. 1073/pnas.1011526108 PMID: 21873180.

Bodmer RE, Puertas P. 2000. Community-based comanagement of wildlife in the Peruvian Amazon. In: Robinson JG, Bennett EL (eds) Hunting for Sustainability in Tropical Forests. (pp. 395-412) Columbia University Press, New York.

Chaves WA, Wilkie DS, Monroe MC, Sieving KE. 2017. Market access and wild meat consumption in the central Amazon, Brazil. Biol $\begin{array}{lll}\text { Conserv } & 212 & \text { (2017): }\end{array}$ http://dx.doi.org/10.1016/j.biocon.2017.06.013.

Cooney N. 2013. Veganomics: The surprising science on what motivates vegetarians, from the breakfast table to the bedroom. Lantern Books.

Corlett RT. 2007. The impact of hunting on the mammalian fauna of Tropical Asian Forests. Biotropica 39(3): 292-303.

Davies G. 2002. Bushmeat and international development. Conserv Biol 16(3): 588-589.

East T, Kümpel NF, Milner-Gulland EJ, Rowcliffe JM. 2005.Determinants of urban bushmeat consumption in Rio Muni, Equatorial Guinea. Biol Conserv 126: 206-215.

Elliott J, Grahn R, Sriskanthan G, Arnold C. 2002. Wildlife and poverty study. Department for International Development, London.

Fa JE, Brown D. 2009. Impacts of hunting on mammals in African tropical moist forests: a review and synthesis. Mammal Rev 39(4): 231-264. 
Fa JE, Yuste JEG. 2001. Commercial bushmeat hunting in the Monte Mitra forests, Equatorial Guinea: extent and impact. Anim Biodivers Conserv 24(1): 31-52.

Fa JE, Albrechtsen L, Johnson PJ, Macdonald DW. 2009. Linkages between household wealth, bushmeat and other animal protein consumption are not invariant: evidence from Rio Muni, Equatorial Guinea. Anim Conserv 12: 599-610.

Fa JE, Yuste JEG, Burn RW, Broad G. 2002a. Bushmeat consumption and preferences of two ethnic groups in Bioko Island, West Africa. Hum Ecol 30(3): 397-415.

Fa JE, Peres CA, Meeuwig, J. 2002b. Bushmeat exploitation in tropical forests: an intercontinental comparison. Conserv Biol 16: 232-237.

Fa JE, Yuste JEG, Castelo R. 2000. Bushmeat markets on Bioko Island as a measure of hunting pressure. Conserv Biol 14: 1602-1613.

Falconer J. 1992. Non-timber forest products in Southern Ghana. A summary report. Natural Resources Institute, Chatham, UK.

Hart JA. 2000. Impact and sustainability of indigenous hunting in the Ituri Forest, Congo-Zaire: a comparison of unhunted and hunted duiker populations. Hunting Sustainabil Trop For 106-153.

Hilaluddin, Kaul R, Ghose D. 2005. Conservation implications of wild animal biomass extractions in Northeast India. Anim Biodivers Conserv 28(2): 169-179.

Inskip C, Zimmermann A. 2009. Human-felid conflict: a review of patterns and priorities worldwide. Oryx 43:18-34.

Kaltenborn BP, Nyahongo JW, Tingstad KM. 2005. The nature of hunting around the western corridor of Serengeti National Park, Tanzania. Eur J Wildl Res 51: 213-222.

Kwapena N. 1984. Traditional conservation and utilization of wildlife in Papua New Guinea. The Environmentalist 4(7): 22-26.

Macdonald DW, Johnson PJ, Alberchtsen L, Dutton A, Seymour S, Dupain J, Hall A, Fa JE. 2011. Association of body mass with price of bushmeat in Nigeria and Cameroon. Conserv Biol 25: 1220-1228.

Mendelson S, Cowlishaw G, Rowcliffe JM. 2003. Anatomy of a bushmeat commodity chain in Takoradi, Ghana. J Peasant Stud 31(1): 73-100.

Nasi R, Brown D, Wilkie D, Bennett E, Tutin C, van Tol G, Christophersen T. 2008. Conservation and use of wildlife-based resources: the bushmeat crisis. Secretariat of the Convention on Biological Diversity, Montreal, and Center for International Forestry Research (CIFOR), Bogor. Technical Series No. 33, (50 pp.)

Milner-Gulland EJ, Bennett E, The SCB 2002 Annual Meeting Wild Meat Group. 2003. Wild meat: the bigger picture. TRENDS in Ecol Evol 18(7): 351-357.

Naranjo EJ, Guerra MM, Bodmer RE, Bolaños JE. 2004. Subsistence hunting by three ethnic groups of the Lacandon Forest, Mexico. J Ethnobiol 24(2): 233-253.

Njiforti HL. 1996. Preferences and present demand for bushmeat in north Cameroon: some implications for wildlife conservation. Environ Conserv 23(2): 149-155.

Ntiamoa-Baidu Y. 1992. Local perceptions and value of wildlife reserves to communities in the vicinity of forest national parks in Western Ghana. In: Protected area development in South-west Ghana Report by the Oxford Environment and Development Group, UK.

Pattiselanno F. 2006. The wildlife hunting in Papua. Biota XI(1): 59-61.

Pattiselanno F, Arobaya AYS. 2009. Grazing habitat of the Rusa deer (Cervus timorensis) in the Upland Kebar, Manokwari. Biodiversitas 10 (3): 134-138.
Pattiselanno F, Lubis MI. 2014. Hunting at the Abun Regional Marine Protected Areas: A link between wildmeat and food security. Hayati J Biosci 21(4): 180-186.

Pattiselanno F, Koibur JF, Yohanes CY. 2015. Traditional Ecological Knowledge (TEK) in Hunting: From Culture to Nature. KnE Social Sciences Vol. 2016, 5 pages. DOI10.18502/2016/kss.v1i1.436.

Pattiselanno F, Koibur JF. 2018. Returns from indigenous hunting in the lowland coastal forests of West Papua, Benefits threatened wildlife species. J Manajemen Hutan Tropika 24(1): 46-50.

Prescott-Allen R, Prescott-Allen C. 1982. What's Wildlife worth? International Institute for Environment and Development, Washington.

Prins HHT, Grootenhuis JG, Dolan TT. 2000. Wildlife conservation by sustainable use. Kluwer Academic Pub.

Rao M, McGowan PJK. 2002. Wild-meat use, food security, livelihoods, and conservation. Conserv Biol 16(3): 580-583.

Rao M, Myint T, Zaw T, Htun S. 2005. Hunting pattern in tropical forests adjoining the Hkakaborazi National Park, north Myanmar. Oryx 39(3): 292-300.

Robinson JG, Bennett EL. 2004. Having your wildlife and eating it too: an analysis of hunting sustainability across tropical ecosystems. Anim Conserv 7: 397-408.

Robinson JG, Bennett EL (Eds.). 2000. Hunting for sustainability in Tropical Forests. Columbia University Press, New York.

Schenk M, Effa NM, Starkey M, Wilkie D, Abernethy K, Telfer P, Godoy R, Treves A. 2006. Why people eat bushmeat: Results from twochoice, taste test in Gabon, Central Africa. Human Ecol 34(3): 433445.

Schulte-Herbrüggen B, Cowlishaw G, Homewood K, Rowcliffe JM. 2017. Rural protein insufficiency in wildlife depleted West African farmforest landscape. PLoSONE 12(12): e0188109. DOI: 10.1371/journal. pone.0188109

Shively GE. 1997. Poverty, technology and wildlife hunting in Palawan. Environ Conserv 24: 57-63.

Siekmann JH, Allen LH, Bwibo NO, Demment MW, Murphy SP, Neumann CG. 2003. Animal source foods to improve micronutrient nutrition and human function in developing countries. J Nutr 133: 3972S-3980S.

Van Vliet N, Nasi R, Taber A. 2011. From the forest to the stomach: Bushmeat consumption from rural to urban settings in Central Africa. In: Shackleton SC, Shackleton C, Shanley P (eds) Non-timber forest products in the global context. Tropical forestry no. 7. SpringerVerlag, Heidelberg, Germany.

Wilkie DS, Carpenter JF. 1999. Bushmeat hunting in the Congo Basin: an assessment of impacts and options for mitigation. Biodivers Conserv 8: 927-955.

Wilkie DS, Starkey M, Abernethy K, Effa EN, Telfer P, Godoy RA. 2005. Role of prices and wealth in consumer demand for bushmeat in Gabon, Central Africa. Conserv Biol 19(1): 268-274.

Williamson D. 2002. Wild meat, food security and forest conservation. In: Mainka SA, Trivedi M (eds) Links between biodiversity conservation, livelihoods and food security: The sustainable use of wild species for meat. International Union for Conservation of Nature, Gland, Switzerland.

Wright JH, Priston NE. 2010. Hunting and trapping in Lebialem Division, Cameroon: bushmeat harvesting practices and human reliance. Endangered Species Res 11: 1-12. 